\title{
Antimicrobial activity of Psidium cattleianum associated with calcium hydroxide against Enterococcus faecalis and Candida albicans: an in vitro study
}

\author{
Jorgiana Sangalli ${ }^{1}$ • Elerson Gaetti Jardim Júnior ${ }^{2}$ - Carlos Roberto Emerenciano Bueno ${ }^{1} \cdot$ Rogério Castilho Jacinto $^{1}$. \\ Gustavo Sivieri-Araújo ${ }^{1}$. João Eduardo Gomes Filho ${ }^{1}$ • Luciano Tavares Ângelo Cintra ${ }^{1}$ • Eloi Dezan Junior ${ }^{1}$
}

Received: 27 August 2017 / Accepted: 21 December 2017 / Published online: 9 January 2018

(C) Springer-Verlag GmbH Germany, part of Springer Nature 2018

\begin{abstract}
Objective Evaluate, in vitro, the antimicrobial activity of Psidium cattleianum leaf extracts combined with calcium hydroxide against Enterococcus faecalis and Candida albicans biofilm.

Materials and methods Dentin specimens obtained from extracted bovine incisors were infected during 14 days with E. faecalis ATCC 29212 and C. albicans ATCC 10231. The specimens were filled with calcium hydroxide pastes prepared with the following vehicles: Psidium cattleianum ethanolic, Psidium cattleianum propylene glycolic, distilled water, and saline as control. After $24 \mathrm{~h}, 3,7$, and 14 days, the canals were irrigated with sterile saline and dried. Dentin samples were collected from the canals with burs of increasing diameters. To determine the number of colony-forming units (CFU), samples were inoculated onto BHI agar supplemented with yeast extract $(0.5 \%)$, at $37^{\circ} \mathrm{C}$, for $48 \mathrm{~h}$, in $\mathrm{CO}_{2}$ enriched atmosphere. Comparisons among the groups for the variation factors were performed by ANOVA and Tukey's test.

Results Ethanolic and propylene glycolic extracts showed significantly higher antimicrobial activity against $E$. faecalis $(p<0.01)$ when compared with distilled water. The ethanolic extract exhibited in $24 \mathrm{~h}$ the same antibacterial activity that propylene glycolic extract and distilled water after 7 and 14 days. For $C$. albicans, all were effective in reducing the number of CFU at all periods. Conclusion The P. cattleianum ethanolic extract presented the fastest and highest antimicrobial activity against $E$. faecalis, significantly reducing the microbial load in $24 \mathrm{~h}$. All medications were effective against C. albicans.

Clinical relevance The antibacterial potential of $P$. cattleianum and its biological compatibility associated with calcium hydroxide indicate promising applications in the field of dentistry.
\end{abstract}

Keywords Calcium hydroxide $\cdot$ Candida albicans $\cdot$ Enterococcus faecalis $\cdot$ Plant extracts

\section{Introduction}

Invasive microorganisms of root canal system and their metabolic products have a key role in the development of pulpal and periapical diseases [1]. One of the goals of biomechanical preparation is to eliminate microorganisms and their products

Eloi Dezan Junior dezan@foa.unesp.br

1 Department of Restorative Dentistry, Endodontics, Araçatuba School of Dentistry, UNESP Univ Estadual Paulista, Rua José Bonifácio, 1193, Araçatuba, SP 16015-050, Brazil

2 Department of Pathology, Microbiology and Imunology, Araçatuba School of Dentistry, UNESP Univ Estadual Paulista, São Paulo, Brazil by associating mechanical action of instrumentation with chemical and physical action of irrigating solutions. The use of intracanal medication is an important stage for success in endodontic therapy.

However, the capacity of certain microorganisms to proliferate and invade dentin tubules hinders the action of chemomechanical preparation [2,3] and may lead to the development of endodontic infections, sometimes refractory to treatment [4]. Unlike most primary endodontic infections, polymicrobial in nature, with predominance of obligate anaerobes, secondary infections are caused by one or few species [5].

Calcium hydroxide $(\mathrm{CH})$ is widely used as intracanal medication in endodontic infections due to its excellent properties, biocompatibility, and capacity of altering the microbial enzymatic metabolism by creating an environment of highly alkaline $\mathrm{pH}$ gradient [6]. However, $\mathrm{CH}$ acts by direct contact [7] 
requiring a disinfection period of more than 7 days [8]. It has been demonstrated that some microorganisms such as Enterococcus faecalis and Candida albicans can resist the action of CH-based medications [9-12].

Candida albicans is the most common yeast isolated from the oral cavity or root canals and has the ability to form bilayer biofilm, rich in an extracellular matrix composed by carbohydrates, proteins, phosphorus, and hexosamines, allowing good tolerance and growth in nutrient-restricted environments, as occurs in retreatment of the canal system [13, 14]. Also, has been considered tolerant to chemical compounds commonly used in the biomechanical instrumentation of infected root canals or dressings, such as calcium hydroxide [15-17], and this resistance may be comparable to that evidenced for E. faecalis [18]; E.faecalis is a cocci Gram-positive anaerobe facultative which occur in primary root canal infections and is the most common organism cultured from failed root canal therapy, with 12-90\% prevalence [19]. Both species exhibit similar starvation survival behaviors and are capable of starvation survival for 6 months, using low levels of serum for growth. These characteristics are conducive to species survival and contribution to posttreatment apical periodontitis [20]. Therefore, the association between E. faecalis and C. albicans is frequently detected in persistent endodontic infections [21-23].

The possibility of using others biocompatible antimicrobial substances may also enhance some effective therapies against oral microorganisms, refractory to conventional chemical agents during treatment. The involvement of E. faecalis, and C. albicans, in those cases deserve special attention [24, 25].

Psidium spp. belongs to the Myrtaceae and is native to tropical America. The capacity of Psidium cattleianum leaf extracts to inhibit growth of both planktonic and biofilm forms of anaerobes such as Streptococcus mutans [26], Porphyromonas gingivalis, Prevotella intermedia and Fusobacterium nucleatum, and microaerophiles or facultative bacteria such as Aggregatibacter actinomycetemcomitans has been previously demonstrated [27]. These extracts also reduce expression of proteins involved in the metabolism, glycolysis, and acid lactic production of S. mutans [28], growth of S. mutans biofilms, and enamel demineralization [29]. Ethanolic extract of Psidium cattleianum leaf has similar biocompatibility to saline [30]. The biocompatibility of $P$. cattleianum extracts used as vehicle for $\mathrm{CH}$ has been recently demonstrated [31], indicating that these extracts have promising applications in the field of dentistry. However, these extracts have not been evaluated against biofilm of E.faecalis and C. albicans.

The aim of this study was evaluate, in vitro, the antimicrobial activity of Psidium cattleianum leaf extracts combined with $\mathrm{CH}$ against biofilms of $E$. faecalis and $C$. albicans. The null hypothesis was that $P$. cattleianum does not improve the antimicrobial activity of calcium hydroxide.

\section{Material and methods}

Psidium cattleianum was grown and collected at UNESPUniv Estadual Paulista, Araçatuba, Brazil, in natural conditions, without addition of chemical compounds such as chemical fertilizers, pesticides, and insecticides. The voucher specimen was deposited at the Herbarium of Pharmacognosy and Phytotherapy under the number HLF2006/71. After washed three times in deionized water, Psidium cattleianum leaves were dried protected from light at $27{ }^{\circ} \mathrm{C}$ during 5 days and at $37^{\circ} \mathrm{C}$ during 15 days until becoming friable. Dried leaves were ground to a fine powder in a blender [31].

To obtain the ethanolic extracts, $5 \mathrm{~g}$ of powder was loaded into the main chamber of the Soxhlet extractor. A total of $150 \mathrm{~mL} 96^{\circ} \mathrm{GL}$ ethanol was placed in Soxhlet extractor. The solvent was heated to reflux for $4 \mathrm{~h}$. The solution was then filter sterilized using cellulose membranes with $0.22 \mu \mathrm{m}$ pore size (Millipore ${ }^{\mathrm{TM}}$; Billerica, USA) and stored in dark bottles. To obtain the propylene glycolic extract, $5 \mathrm{~g}$ of powder was placed in a percolator and subjected to lixiviation with $150 \mathrm{~mL}$ of propylene glycol. The extract was filtered, sterilized, and stored as previously described.

The dentin blocks were obtained from freshly extracted bovine incisors and prepared according to Haapasalo and Orstavik [32]. Teeth were decoronated and the apical third removed to obtain root blocks measuring approximately $4 \mathrm{~mm}$ in height. Root canal lumen was standardized to a diameter of $1.8 \mathrm{~mm}$ with stainless steel round burs (ISO 018, Maillefer/Dentsply, Switzerland). After canal preparation, smear layer was removed in ultrasonic bath with 17\% EDTA during $10 \mathrm{~min}$, followed by ultrasonic bath with distilled water during $15 \mathrm{~min}$, and washed in running water during $1 \mathrm{~h}$. The dentin blocks were autoclaved, dried, and externally coated with nail varnish.

The sterile dentin blocks were transferred to test tubes containing $5 \mathrm{~mL}$ of brain heart infusion (BHI) broth (Difco Laboratories, Detroit, MI, USA) supplemented with yeast extract $(0.5 \%)$ and glucose $(1 \%)$ and incubated at $37^{\circ} \mathrm{C}$ during $24 \mathrm{~h}$ for sterility test. Then, an inoculum of $10^{6}$ colonyforming units (CFU) of E. faecalis ATCC-29212 was transferred aseptically to dentin tubules and the mixture incubated at $37^{\circ} \mathrm{C}$ for 14 days, at $\mathrm{CO}_{2}$ enriched atmosphere. At the 8th day after inoculation of $E$. faecalis, $10^{6} \mathrm{CFU}$ of $C$. albicans ATCC-10231 were also inoculated. In order to provide fresh culture medium, all BHI supplemented broth was substituted daily and at every change of culture medium, exogenous microbial contamination was checked by mean of inoculation on BHI supplemented agar, incubated at $37{ }^{\circ} \mathrm{C}$ for $48 \mathrm{~h}$. Microbial identification was performed by morphocolonial and morphocellular analysis to confirm existence of culture formed only by enterococci and yeasts.

To evaluate the antibacterial effect of intracanal dressing, eight dentin blocks with $0.85 \%$ saline formed the control group, and three experimental groups $(n=16)$ with different 
vehicles were used for preparation of $\mathrm{CH}$-based intracanal medications: ethanolic extract of Psidium cattleianum leaf $(1 \mathrm{~g} / \mathrm{mL})+\mathrm{CaOH}_{2}$; propylene glycolic extract of Psidium cattleianum leaf $(1 \mathrm{~g} / \mathrm{mL})+\mathrm{CaOH}_{2}$; and distilled water $(1 \mathrm{~g} /$ $\mathrm{mL})+\mathrm{CaOH}_{2}$, as a positive control group. In a laminar flow chamber, $20 \mathrm{~mL}$ of BHI agar was poured into $20 \times 10 \mathrm{~mm}$ sterile Petri dishes. After solidification, wells were made at equidistant. The root canals were filled with the medications, and their ends sealed with sterile wax to maintain material moisture. Each well received one dentin block.

Using candle jar technique, specimens were incubated at $37^{\circ} \mathrm{C}$ in microaerophilia in glass desiccators for $24 \mathrm{~h}, 3,7$, and 14 days in duplicate. Concluded each experimental period, in a laminar flow chamber, dentin blocks were removed from culture and their external surface disinfected with alcohol $70 \%$. The canals were flushed with $5 \mathrm{~mL}$ of sterile saline for removal of intracanal medication and dried with sterile paper points.

Each dentin block was secured with a sterile Mayo-Hegar needle holder, at the open end of a test tube with $1 \mathrm{~mL}$ of saline. Burs of increasing diameter (ISO 021, 023, 025, and 027 ) rotating at $300 \mathrm{rpm}$ were used to remove intracanal dentin at different depths. The first bur removed $300 \mu \mathrm{m}$ of dentin and each subsequent bur $200 \mu \mathrm{m}$. The test tube with dentin chips and saline was vortexed during $30 \mathrm{~s}$.

Serial tenfold dilutions of the suspension were prepared, and $0.1 \mathrm{~mL}$ of solution was inoculated onto BHI agar supplemented with yeast extract $(0.5 \%)$, incubated at $37^{\circ} \mathrm{C}$, for $48 \mathrm{~h}$, in $\mathrm{CO}_{2}$-enriched atmosphere. After incubation, $\mathrm{CFU}$ in the different dilutions was enumerated using a digital colony counter.

The results were expressed as CFU per $0.1 \mathrm{~mL}$ of solution. Comparisons among the groups for the variation factors "evaluation period," "dentin depth," and "intracanal medication" as well as the interactions among the factors were done by ANOVA and Tukey's test. A significance level of 5\% was set for all analyses.

\section{Results}

Saline presented no antimicrobial activity, exhibiting a large number of viable microorganisms at all periods. All $\mathrm{CH}-$ pastes presented antimicrobial activity. Tables 1 and 2 present the mean values of $E$. faecalis and $C$. albicans $C F U$ in the samples collected from the canals at different depths and periods.

Concerning the depth of collected dentin samples, there was no statistically significant difference in E. faecalis CFU number $(p>0.05)$ among the groups, regardless of the evaluation period and intracanal medication. When analyzing only the evaluation period, there was a significant factor $(p=$ 0.000001 ), showing more accentuated reduction in the number of microorganisms at 7 and 14 days.
On enterococci, the association of $\mathrm{CH}$ with ethanolic and propylene glycolic Psidium cattleianum extracts showed higher antimicrobial activity than $\mathrm{CH}$ with distilled water ( $p=0.000002$ ). Comparing only herbal medications, $\mathrm{CH}-$ paste prepared with ethanolic extract presented significantly higher $(p=0.000212)$ antimicrobial activity than propylene glycolic extract.

The combination of $\mathrm{CH}$ and ethanolic extract exhibited in $24 \mathrm{~h}$ the same reduction of microorganisms than $\mathrm{CH}$-pastes prepared with distilled water and propylene glycolic extract after 7-14 days. At $24 \mathrm{~h}, \mathrm{CH}$ associated with propylene glycolic extract was significantly more effective than its association with distilled water $(p<0.05)$. At 7 and 14 days, all pastes had similar antibacterial action, evidencing profound microbial load reduction (Fig. 1).

For $C$. albicans, all medications were significantly effective in reducing CFU counts at all periods (Table 2).

\section{Discussion}

In the present study, the association of $P$. catleianum with calcium hydroxide enhanced the antimicrobial activity of the paste, significantly reducing the microbial load, rejecting the null hypothesis.

The presence of a large number of CFU in control group, up to 14 days in different depths, confirms the methodology effectiveness in producing fcontamination in dentin tubules, surpassing the 10-day experimental period without nutrients used by Orstavik and Haapasalo [9, 32]. Bacteria were retrieved from all dentin depths. At $900 \mu \mathrm{m}$ (ISO 027), there was a tendency to a larger number of CFU, which was expected due to the distance from the medicated root canal lumen.

The choice of C.albicans and E.faecalis in this study was because of the frequency this association is found in endodontic disease [21, 33, 34]. The ability to form biofilms is considered one of the reasons why $C$. albicans is more pathogenic than other Candida species that are less capable to form these complex structures [35], which allows adaptability to starvation, even surviving in environmental unfavorable conditions, and also the ability of morphologic polymorphism [36].

Calcium hydroxide is widely used as an intracanal dressing due to its alkaline $\mathrm{pH}$, leading to antibacterial properties, ability to stimulate mineralization, and tissue-dissolving capability $[37,38]$, therefore, used in the present study associated with distilled water, as a positive control group. However, alkalization caused by hydroxyl ions is slow, since the ionic dissociation and diffusion depend on the vehicle employed, which differs on hydrosolubility, viscosity, and dentinal permeability [39]. Despite its use in endodontics, both $E$. faecalis and $C$. albicans are very resistant to the action of calcium hydroxide [40-42], and its mixing with another medicament 
Table 1 Mean values of Enterococcus faecalis colonyforming units in the samples collected from the samples at different dentin depths after treatment with the experimental groups for different periods

\begin{tabular}{llllll}
\hline $\begin{array}{l}\text { Experimental } \\
\text { groups }\end{array}$ & $\begin{array}{l}\text { Evaluation period } \\
\text { (days) }\end{array}$ & \multicolumn{4}{l}{ Dentin depth (bur) } \\
\cline { 3 - 6 } & & $\begin{array}{l}300 \mu \mathrm{m} \\
\text { (ISO 021) }\end{array}$ & $\begin{array}{l}500 \mu \mathrm{m} \\
\text { (ISO 023) }\end{array}$ & $\begin{array}{l}700 \mu \mathrm{m} \\
(\text { ISO 025) }\end{array}$ & $\begin{array}{l}900 \mu \mathrm{m} \\
\text { (ISO 027) }\end{array}$ \\
\hline $\mathrm{CH}+$ distilled water & 1 & $62.7 \pm 17.1$ & $102.7 \pm 81.8$ & $68 \pm 64.8$ & $218 \pm 158.5$ \\
& 3 & $159.2 \pm 128.6$ & $31.7 \pm 33.9$ & $44.2 \pm 36.2$ & $11.2 \pm 11.8$ \\
& 7 & $5.7 \pm 6.6$ & $7.5 \pm 14.3$ & $2.0 \pm 4.0$ & $1.7 \pm 2.2$ \\
& 14 & $4.5 \pm 4.7$ & $6.7 \pm 10.9$ & $3.7 \pm 5.7$ & $2.7 \pm 3.1$ \\
$\mathrm{CH}+\mathrm{EEPc}$ & 1 & 0 & $0.5 \pm 0.6$ & $0.5 \pm 1.0$ & $2.7 \pm 3.8$ \\
& 3 & 0 & 0 & $1.7 \pm 1.7$ & $5.0 \pm 4.2$ \\
& 7 & $1.5 \pm 1.9$ & 0 & $0.7 \pm 1.5$ & $2.0 \pm 3.0$ \\
$\mathrm{CH}+\mathrm{PEPc}$ & 14 & 0 & 0 & 0 & 0 \\
& 1 & $1.7 \pm 3.5$ & $50.2 \pm 70.2$ & $19.2 \pm 21.1$ & $29.5 \pm 57.7$ \\
& 3 & $20.2 \pm 23.7$ & $35 \pm 21.8$ & $36.5 \pm 35.3$ & $79 \pm 69.0$ \\
& 7 & 0 & 0 & $1.5 \pm 2.4$ & $2.5 \pm 4.4$ \\
Control & 14 & $0.5 \pm 1.0$ & 0 & $1 \pm 0.8$ & 0 \\
& 1 & 333,000 & 32,500 & 12,500 & 46,500 \\
& 3 & 326,000 & 85,500 & 14,000 & 54,000 \\
& 7 & 100,500 & 19,000 & 12,000 & 26,500 \\
& 14 & 84,500 & 19,000 & 10,500 & 29,500 \\
\hline
\end{tabular}

$C H$ calcium hydroxide, EEPC ethanolic extract of Psidium cattleianum leaf, $P E P C$ propylene glycolic extract of Psidium cattleianum leaf could improve significantly the antimicrobial effect [43, 44], since most of the substances used as a vehicle for calcium hydroxide do not have significant antimicrobial activity. A research conducted by Dezan-Junior [45] showed that the association of calcium hydroxide and Psidium cattleianum eliminated E. faecalis in $24 \mathrm{~h}$, corroborating a recent study with hydroethanolic association [46], suggesting that only the presence of the leaf extract produced bactericidal effect.
Table 2 Mean values of Candida albicans colony-forming units in the samples collected from the samples at different dentin depths after treatment with the experimental groups for different periods

\begin{tabular}{|c|c|c|c|c|c|}
\hline \multirow{2}{*}{$\begin{array}{l}\text { Experimental } \\
\text { groups }\end{array}$} & \multirow{2}{*}{$\begin{array}{l}\text { Evaluation period } \\
\text { (days) }\end{array}$} & \multicolumn{4}{|c|}{ Dentin depth (bur) } \\
\hline & & $\begin{array}{l}300 \mu \mathrm{m} \\
\text { (ISO 021) }\end{array}$ & $\begin{array}{l}500 \mu \mathrm{m} \\
(\text { ISO 023) }\end{array}$ & $\begin{array}{l}700 \mu \mathrm{m} \\
\text { (ISO 025) }\end{array}$ & $\begin{array}{l}900 \mu \mathrm{m} \\
\text { (ISO 027) }\end{array}$ \\
\hline \multirow[t]{4}{*}{$\mathrm{CH}+$ distilled water } & 1 & 0 & $0.25 \pm 0.5$ & 0 & 0 \\
\hline & 3 & 0 & 0 & 0 & 0 \\
\hline & 7 & $3.25 \pm 5.9$ & 0 & $0.25 \pm 1.0$ & $0.25 \pm 0.5$ \\
\hline & 14 & $1.75 \pm 3.5$ & $0.25 \pm 0.5$ & 0 & 0 \\
\hline \multirow[t]{4}{*}{$\mathrm{CH}+\mathrm{EEPc}$} & 1 & 0 & $0.5 \pm 0.6$ & $0.5 \pm 1.0$ & $2.7 \pm 3.8$ \\
\hline & 3 & 0 & 0 & 0 & 0 \\
\hline & 7 & 0 & 0 & 0 & 0 \\
\hline & 14 & 0 & 0 & 0 & 0 \\
\hline \multirow[t]{4}{*}{$\mathrm{CH}+\mathrm{PEPc}$} & 1 & 0 & 0 & 0 & 0 \\
\hline & 3 & 0 & 0 & 0 & 0 \\
\hline & 7 & $1.0 \pm 2.0$ & 0 & 0 & 0 \\
\hline & 14 & 0 & 0 & 0 & 0 \\
\hline \multirow[t]{4}{*}{ Control } & 1 & 7000 & 1500 & 1000 & 1000 \\
\hline & 3 & 21,500 & 9000 & 1000 & 1000 \\
\hline & 7 & 2500 & 4000 & 1000 & 4000 \\
\hline & 14 & 7000 & 1500 & 1000 & 1500 \\
\hline
\end{tabular}

$C H$ calcium hydroxide, EEPc ethanolic extract of Psidium cattleianum leaf, PEPC propylene glycolic extract of Psidium cattleianum leaf 


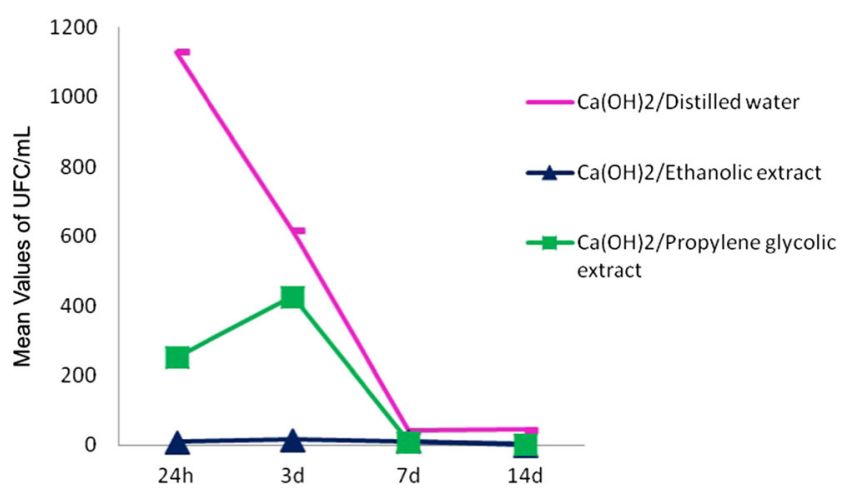

Fig. 1 Mean values of Enterococcus faecalis colony-forming units according to contact time of the associations in different experimental time periods

The microbial inoculation sequence used in this study was performed according to the proliferation ability of the E.faecalis and C.albicans. When Enterococcus faecalis was inoculated prior, the growth of yeasts was not affected. However, when Candida albicans was inoculated first, the growth of $E$. faecalis into de dentinal tubules was significantly affected, probably due to formation of aggregates of yeasts, pseudohyphae, and hyphae on dentinal tubules, as previously reported $[3,13,15,47]$. At the 8 th day after initial inoculation, the contamination by enterococci was high and reached the highest values. By this moment, it was decided to inoculate the yeasts, which took 5-7 days to produce invasion of dentinal tubules.

In our study, both associations prepared with Psidium cattleianum extracts presented higher inhibitory activity in the first $24 \mathrm{~h}$ than the aqueous product. In addition, ethanolic extract exhibited higher activity than the propylene glycolic extract, reducing the time necessary to reach the maximum action within $24 \mathrm{~h}$ against $E$. faecalis, which reportedly tolerant to alkalinity [48] and frequently involved in refractory infections or endodontic retreatment [4]. The better results achieved by the intracanal medications prepared with plant extracts are probably due to the fact that the $P$. cattleianum leaves contain flavonoids (kaempferol, quercetin, cyanidin) and tannins (ellagic acid), which have recognized antibacterial activity [49]. Flavonoids are secondary metabolites naturally synthesized by plants in response to microbial infection [50], and their action is attributed to capacity of forming complexes with extracellular proteins [51]; tannins can be toxic to filamentous fungi, yeasts, and bacteria [52]. Therefore, this abundance of phenolic compounds is directly related to the antimicrobial activity, once this phenolic toxicity to microorganisms is caused by enzyme inhibition by the oxidized form of the phenolic compound [53].

A possible explanation for the faster inhibitory action of the ethanolic extract is that this extraction mode may provide greater amounts of active principles. Another explanation is related to the physical properties of propylene glycol: as this vehicle presents greater viscosity and surface tension than ethanol, its penetration into dentin tubules is expected to occur at a slower rate.

All CH-based pastes were significantly effective in reducing C. albicans $\mathrm{CFU}$ number at all periods. This result is probably due to the lower tolerance of $C$. albicans to the enzymatic inhibition promoted by $\mathrm{CH}$ and to the fact that these yeasts have a more superficial location than enterococci in biofilms formed inside dentin tubules [3]. On the other hand, using a different methodology, Waltimo et al. [10] showed resistance of $C$. albicans even in direct contact with $\mathrm{CH}$.

\section{Conclusions}

The potent antimicrobial activity of intracanal medications associating $\mathrm{CH}$ and Psidium cattleianum extracts is a promising option for clinical use. From our results, it may be concluded that the paste prepared with $\mathrm{CH}$ and the ethanolic extract had the fastest action, exhibiting maximum antimicrobial activity against biofilms of $E$. faecalis and $C$. albicans in the first $24 \mathrm{~h}$.

Funding This research was suported by the Conselho Nacional de Desenvolvimento Científico e Tecnológico (CNPq)-Brazil.

\section{Compliance with ethical standards}

Conflict of interest The authors declare that they have no conflict of interest.

Ethical approval This article does not contain any studies with human participants or animals performed by any of the authors.

Informed consent For this type of study, formal consent is not required.

\section{References}

1. Kakehashi S, Stanley HR, Fitzgerald RJ (1965) The effects of surgical exposures of dental pulps in germ-free and conventional laboratory rats. Oral Surg Oral Med Oral Pathol 20(3):340-349. https://doi.org/10.1016/0030-4220(65)90166-0

2. Bystrom A, Sundqvist G (1981) Bacteriologic evaluation of the efficacy of mechanical root canal instrumentation in endodontic therapy. Scand J Dent Res 89(4):321-328

3. Waltimo TMT, Orstavik D, Sirén EK, Haapasalo MPP (2000) In vitro yeast infection of human dentin. J Endod 26(4):207-209. https://doi.org/10.1097/00004770-200004000-00002

4. Safavi KE, Spangberg SW, Langeland K (1990) Root canal dentinl tubule disinfection. J Endod 16(5):207-210. https://doi.org/10. 1016/S0099-2399(06)81670-5

5. Cogulu D, Uzel A, Oncag O, Eronat C (2008) PCR-based identification of selected pathogens associated with endodontic infections in deciduous and permanent teeth. Oral Surg Oral Med Oral Pathol Oral Radiol Endod 106(3):443-449. https://doi.org/10.1016/j. tripleo.2008.03.004 
6. Estrela C, Sydney GB, Bammann LL, Felippe-Jr O (1995) Mechanism of the action of calcium and hydroxyl ions of calcium hydroxide on tissue and bacteria. Braz Dent J 6(2):85-90

7. Siqueira JF Jr, Lopes HP (1999) Mechanisms of antimicrobial activity of calcium hydroxide: a critical review. Int Endod J 32:361-369

8. Sjogren U, Figdor D, Spangberg L, Sundqvist G (1991) The antimicrobial effect of calcium hydroxide as a short-term intracanal dressing. Int Endod J 24(3):119-125. https://doi.org/10.1111/j. 1365-2591.1991.tb00117.x

9. Orstavik D, Haapasalo M (1990) Disinfection by endodontic irrigants and dressings of experimentally infected dentinl tubules. Endod Dent Traumatol 6(4):142-149. https://doi.org/10.1111/j. 1600-9657.1990.tb00409.x

10. Waltimo TMT, Orstavik D, Sirén EK, Haapasalo MPP (1999) In vitro susceptibility of Candida albicans to four disinfectants and their combinations. Int Endod J 32(6):421-429. https://doi. org/10.1046/j.1365-2591.1999.00237.x

11. Evans M, Davies JK, Sundqvist G, Figdor D (2002) Mechanisms involved in the resistance of Enterococcus faecalis to calcium hydroxide. Int Endod J 35(3):221-228. https://doi.org/10.1046/j. 1365-2591.2002.00504.x

12. George S, Kishen A, Song KP (2005) The role of environmental changes on monospecies biofilm formation on root canal wall by Enterococcus faecalis. J Endod 31(12):867-872. https://doi.org/10. 1097/01.don.0000164855.98346.fc

13. Turk BT, Ates M, Sen BH (2008) The effect of treatment of radicular dentin on colonization patterns of C. albicans. Oral Surg Oral Med Oral Pathol Oral Radiol Endod 106(3):457-462. https://doi. org/10.1016/j.tripleo.2008.05.012

14. Araújo A, Henriques M, Silva S (2017) Portrait of Candida species biofilm regulatory network genes. Trends Microbiol 25(1):62-75. https://doi.org/10.1016/j.tim.2016.09.004

15. Delgado RJR, Gasparoto TH, Sipert CR, Pinheiro CR et al (2013) Antimicrobial activity of calcium hydroxide and chlorhexidine on intratubular Candida albicans. Int J Oral Sci 5(1):32-36. https://doi. org/10.1038/ijos.2013.12

16. Mejía JBC (2014) Antimicrobial effects of calcium hydroxide, chlorhexidine, and propolis on enterococcus faecalis and Candida albicans. J Investig Clin Dent 5(3):194-200. https://doi.org/10. 1111/jicd.12041

17. Paikkatt JV, Sreedharan S, Philomina B, Kannan VP, Santhakumar M, Kumar TVA (2017) Eficacy of various intracanal medicaments in human primary teeth with necrotic pulp against Candida biofillms: an in vivo study. Int J Clin Pediatr Dent 10(1):45-48. https://doi.org/10.5005/jp-journals-10005-1406

18. Waltimo TM, Sirén EK, Ørstavik D, Haapasalo MP (1999) Susceptibility of oral Candida species to calcium hydroxide in vitro. Int Endod J 32(2):94-98. https://doi.org/10.1046/j.13652591.1999.00195.x

19. Fouad AF, Zerella J, Barry J, Spanberg LS (2005) Molecular detection of enterococcus species in root canals of therapy-resistant endodon-tic infections. Oral Surg Oral Med Oral Pathol Oral Radiol Endod 99(1):112-118. https://doi.org/10.1016/j.tripleo. 2004.06.064

20. Richards D, Davies JK, Figdor D (2010) Starvation survival and recovery in serum of Candida albicans compared with Enterococcus faecalis. Oral Surg Oral Med Oral Pathol Oral Radiol Endod 110(1):125-130. https://doi.org/10.1016/j.tripleo. 2010.03.007

21. Waltimo TM, Sirén EK, Torkko HL, Olsen I, Haapasalo MP (1997) Fungi in therapy-resistant apical periodontitis. Int Endod J 30(2): 96-101. https://doi.org/10.1111/j.1365-2591.1997.tb00681.x

22. Stuart CH, Schwartz SA, Beeson TJ, Owatz CB (2006) Enterococcus faecalis: its role in root canal treatment failure and current concepts in retreatment. J Endod 32(2):93-98. https://doi. org/10.1016/j.joen.2005.10.049

23. Persoon IF, Crielaard W, Ozok AR (2017) Prevalence and nature of fungi in root canal infections: a systematic review and meta-analysis. Int Endod J 50(11):1055-1066. https://doi.org/10.1111/iej. 12730

24. Ercan E, Dalli M, Dülgergil CT (2006) In vitro assessment of the effectiveness of chlorhexidine gel and calcium hydroxide paste with chlorhexidine against Enterococcus faecalis and Candida albicans. Oral Surg Oral Med Oral Pathol Oral Radiol Endod 102:27-31

25. Roças IN, Siqueira JF, Santos KR (2004) Association of Enterococcus faecalis with different forms or periradicular diseases. J Endod 30(5):315-320. https://doi.org/10.1097/00004770200405000-00004

26. Salineiro FCS, Bianco KG, Gaetti Jardim-Júnior E (2009) Evaluation of antimicrobial activity of plant extracts from the Brazilian savannah on Streptococcus mutans. J Appl Oral Sci; n. Esp.: 485 abstract 307

27. Sangalli J, Dezan E Jr, Gaetti-Jardim E Jr (2009) Antimicrobial activity of six plant extracts from the Brazilian savanna on microbial biofilms. Braz Oral Res 23(Supplement 1):294 Abstract $\mathrm{PNe} 073$

28. Brighenti FL, Luppens SBI, Delbem ACB et al (2008) Effect of Psidium cattleianum leaf extract on Streptococcus mutans viability, protein expression and acid production. Caries Res 42(2):148-154. https://doi.org/10.1159/000121439

29. de Menezes TEC, Delbem ACB, Brighenti FL, Okamoto AC, Gaetti-Jardim E Jr (2010) Protective efficacy of Psidium cattleianum and Myracrodruon urundeuva aqueous extracts against caries development in rats. Pharm Biol 48(3):300-305. https://doi. org/10.3109/13880200903122202

30. Ruviére DB, Machado AC, Novais RZ, Gaetti Jardim-Junior E, Dezan Jr E (2009) Evaluation of the tissue response to inactivated microorganisms associated with aqueous and hydroalcoholic araça (Psidium cattleianum) solutions. J Appl Oral Sci; n. Esp. 432 abstract 019

31. Valentim D, Bueno CRE, Marques VAS, Vasques AMV, Cury MTS, Cintra LTA, Dezan Junior E (2017) Calcium hydroxide associated with a new vehicle: Psidium cattleianum leaf extracts. Tissue response evaluation. Braz Oral Res 31:1-8

32. Haapasalo M, Orstavik D (1987) In vitro infection and disinfection of dentinal tubules. J Dent Res 66(8):1375-1379. https://doi.org/10. 1177/00220345870660081801

33. Peciuliene V, Reynaud AH, Balciuniene I, Haapasalo M (2001) Isolation of yeasts and enteric bacteria in root-filled teeth with chronic apical periodontitis. Int Endod J 34(6):429-434. https:// doi.org/10.1046/j.1365-2591.2001.00411.x

34. Pinheiro ET, Gomes BPFA, Ferraz CCR, Sousa ELR, Teixeira FB, Souza-Filho FJ (2003) Microorganisms from canals of root-filled teeth with periapical lesions. Int Endod J 36(1):1-11. https://doi. org/10.1046/j.1365-2591.2003.00603.x

35. Haynes K (2001) Virulence in Candida species. Trends Microbiol 9(12):591-596. https://doi.org/10.1016/S0966-842X(01)02237-5

36. Miranda TT, Vianna CR, Rodrigues L, Rosa CA, Corrêa A Jr (2015) Differential proteinase patterns among Candida albicans strains isolated from root canal and lingual dorsum: possible roles in periapical disease. J Endod 41(6):841-845. https://doi.org/10. 1016/j.joen.2015.01.012

37. Foreman PC, Barnes IE (1990) A review of calcium hydroxide. Int Endod J 23(6):283-297. https://doi.org/10.1111/j.1365-2591.1990. tb00108.x

38. Hasselgren G, Olsson B, Cvek M (1988) Effects of calcium hydroxide and sodium hypoclorite on the dissolution of necrotic porcine muscle tissue. J Endod 14(3):125-127. https://doi.org/10.1016/ S0099-2399(88)80212-7 
39. Gomes BPFA, Montagner F, Berber VB, Zaia AA, Ferraz CCR, Almeida JFA, Souza-Filho FJ (2009) Antimicrobial action of intracanal medicaments on the external root surface. J Dent 37(1): 76-81. https://doi.org/10.1016/j.jdent.2008.09.009

40. Basrani B, Tjarderhanne L, Santos M, Pascon E, Grad H, Lawrence HP, Friedman S (2003) Efficacy of chlorhexidine and calcium hydroxide-containing medicaments against enterococcus faecalis in vitro. Oral Med Oral Surg Oral Pathol Oral Radiol Endod 96(5):618-624. https://doi.org/10.1016/S1079-2104(03)00166-5

41. Siqueira JF, Rocas IN, Lopes HP, Magalhaes FAC, Uzeda M (2003) Elimination of Candida albicans infection of the radicular dentin by intracanal medications. J Endod 29(8):501-504. https://doi.org/10. 1097/00004770-200308000-00003

42. McHugh CP, Zhang P, Michalek S, Eleazer PD (2004) pH required to kill enterococcus faecalis in vitro. J Endod 30(4):218-219. https://doi.org/10.1097/00004770-200404000-00008

43. Gomes BPFA, Ferraz CCR, Garrido FD et al (2002) Microbial susceptibility to calcium hydroxide pastes and their vehicles. J Endod 28(11):758-761

44. Haenni S, Schmidlin PR, Mueller B, Sener B, Zehnder M (2003) Chemical and antimicrobial properties of calcium hydroxide mixed with irrigating solutions. Int Endod J 36(2):100-105. https://doi. org/10.1046/j.1365-2591.2003.00629.x

45. Dezan-Junior E, Sangalli J, Gomes-Filho JE, Gaetti-Jardim E Jr (2010) Psidium cattleianum plus $\mathrm{Ca}(\mathrm{OH}) 2$ antimicrobial efficacy against Enterococcus faecalis. IADR J Dent Res 89:15-16 Special Issue $\mathrm{B}$
46. Massunari L, Novais RZ, Oliveira MT, Valentim D, Dezan-Junior E, Duque C (2017) Antimicrobial activity and biocompatibility of the Psidium cattleianum extracts for endodontic purposes. Braz Dent J 28(3):372-379. https://doi.org/10.1590/01036440201601409

47. Siqueira JF Jr, Rôças IN, Lopes HP, Elias CN, de Uzeda M (2002) Fungal infection of the radicular dentin. J Endod 28:770-773

48. Bystrom A, Claesson R, Sundqvist G (1985) The antibacterial effect of camphorated paramonochlorophenol, camphorated phenol and calcium hydroxide in the treatment of infected root canals. Endod Dent Traumatol 1(5):170-175. https://doi.org/10.1111/j. 1600-9657.1985.tb00652.x

49. National Genetic Resources Program, United States Department of Agriculture (2005) Agricultural research service: phytochemical and ethnobotanical databases (online database). Beltsville, National Germplasm Resources Laboratory

50. Dixon RA, Dey PM, Lamb CJ (1983) Phytoalexins: enzymology and molecular biology. Adv Enzymol Relat Areas Mol Biol 55:1-136

51. Cowan MM (1999) Plant products as antimicrobial agents. Clin Microbiol Rev 12(4):564-582

52. Scalbert A (1991) Antimicrobial properties of tannins. Phytochemistry 30(12):3875-3883. https://doi.org/10.1016/00319422(91)83426-L

53. Mason TL, Wasserman BP (1987) Inactivation of red beet betaglucan synthase by native and oxidized phenolic compounds. Phytochemistry 26(8):2197-2202. https://doi.org/10.1016/S00319422(00)84683-X 